\title{
ASSESSING RISKS FROM GLACIER HAZARDS IN HIGH MOUNTAIN REGIONS: SOME EXPERIENCES IN THE SWISS ALPS
}

\author{
by \\ W. Haeberli, J.-C. Alean, P. Müller, and M. Funk \\ (Versuchsanstalt für Wasserbau, Hydrologie und Glaziologie, ETH Zentrum, CH-8092 Zürich, \\ Switzerland)
}

\section{ABSTRACT}

Assessing risks from potential glacier hazards in relation to safety considerations for settlements and other fixed installations in high mountain areas requires the application of experience gained from previous events, combined with simple rules derived from basic glaciological theory. The general characteristics of steep, and usually unmeasured, glaciers can be estimated on the basis of a rough parameterization scheme. Variations in glacier length, ice avalanches, and glacier floods then have to be considered for time periods ranging from a few years up to a few decades. As a result of such systematic assessments, maps of potentially dangerous zones can be prepared. Although the inhabitants of many Alpine villages have always lived with the risk of glacier hazards, it now appears that modern construction work, especially that connected with the development of tourism, has started to infiltrate previously avoided high-risk zones more and more. In order to plan reasonable safety measures, risks from glacier hazards have to be compared with those from other natural hazards in mountain areas, such as snow avalanches, landslides, rock falls, or storm-induced floods. Decisions about the acceptable level of risk are difficult and subjective; they are also often influenced by political and economical considerations rather than by scientific reasoning.

\section{INTRODUCTION}

In densely populated high mountain regions, settlements and other fixed features such as roads, railways, cable cars, ski runs, and hydro-electric schemes can exist within the potential hazard zones of glaciers. Demand for an integrated assessment of risks from glacier hazards usually arises either after a destructive event or in connection with environmental impact studies related to the granting of exploitation concessions. Glacier hazards concerning mountain climbers are not considered in this context. The problems involved are comparable with those encountered in other aspects of high mountain hazard, such as snow avalanches, slope instability, rock falls, and so on (Kienholz, 1981; Kienholz and others, 1984; Gubler, 1986; Jaccard, 1988), and co-operation with the appropriate specialists is often desirable. When trying to evaluate glacier hazards, one must be aware of apparently trivial, but nevertheless fundamentally important, principles. As a basic requirement, for instance, the expert must state clearly what is factual and firmly known and what are the main uncertainties of any situation. Emotional or speculative judgements are sometimes made by various parties, but cannot and must not replace the use of objective criteria since inappropriate statements can cause more damage than the dangerous, hazard-generating process itself. Realistic treatment of problems and the practicality of recommendations following a study have absolute priority. The application of complex theories and sophisticated but poorly calibrated models is therefore severely limited. Moreover, in reality, scientific reasoning can only be a part of a complex decision-making process which in turn is also heavily influenced by psychological, historical, economic, and political reflections. Even in rather rare cases of well-defined and specific questions, consideration of the entire situation in its full complexity and careful comparison of the various hazard potentials involved is required in order that essential aspects are not overlooked.

The aims of integrated glacier-hazard assessment studies are to give an overview of potential problems, to set priorities concerning the involved risks and possible measures to be taken, to develop plans for monitoring critical developments, to clarify the allocation of responsibilities, and to reach, amongst the authorities and people concerned, awareness of the important aspects, acceptability and proportionality of risks, even though it may prove difficult to make rational judgements. Advance and retreat of glaciers, ice avalanches, glacier floods, and possible combinations of these processes must normally be considered over time periods ranging from several years to several decades. Because unmeasured glaciers are often involved, and statistical treatment is rarely possible, simple rules derived from basic glaciological theory and also especially from previous experience must be used. There follows a brief review of the procedure currently applied in the Swiss Alps. Reference is made to the research which essentially forms the basis for these procedures.

\section{DETERMINATION OF PARAMETERS FOR UN-} MEASURED GLACIERS

In order roughly to estimate basic glaciological characteristics of the glaciers under consideration, a simple and mainly empirical determination of parameters scheme must be applied. The procedure is virtually the same as the one applied for paleoglaciological reconstructions. Since no reliable basis exists for taking into account the precise magnitude of such important processes as surface-energy balance or sliding at the glacier bed, semi-quantitative results are the best that can be expected; there is no possibility of performing reasonable error analysis on the data used.

As a first step in the scheme, the surface area, $S$, the length, $L$, along the central flow line, which is assumed to be perpendicular to the contour lines, the height, $H$, and the average surface slope, $\alpha$, of each glacier are determined from glacier inventories and/or from appropriate maps. Next, the equilibrium line altitude, ELA, is estimated using either an accumulation area ratio, AAR, of around 0.67 , or mean/median glacier elevations (Gross and others, 1976; Braithwaite and Müller, 1980), and the mean annual air temperature at the ELA, $T_{\mathrm{E}}$, is calculated on the basis of meteorological data and reasonable environmental lapse rates. From $T_{\mathrm{E}}$, glacier/permaf rost relationships, near-surface firn and ice temperatures, as well as average mass-balance 


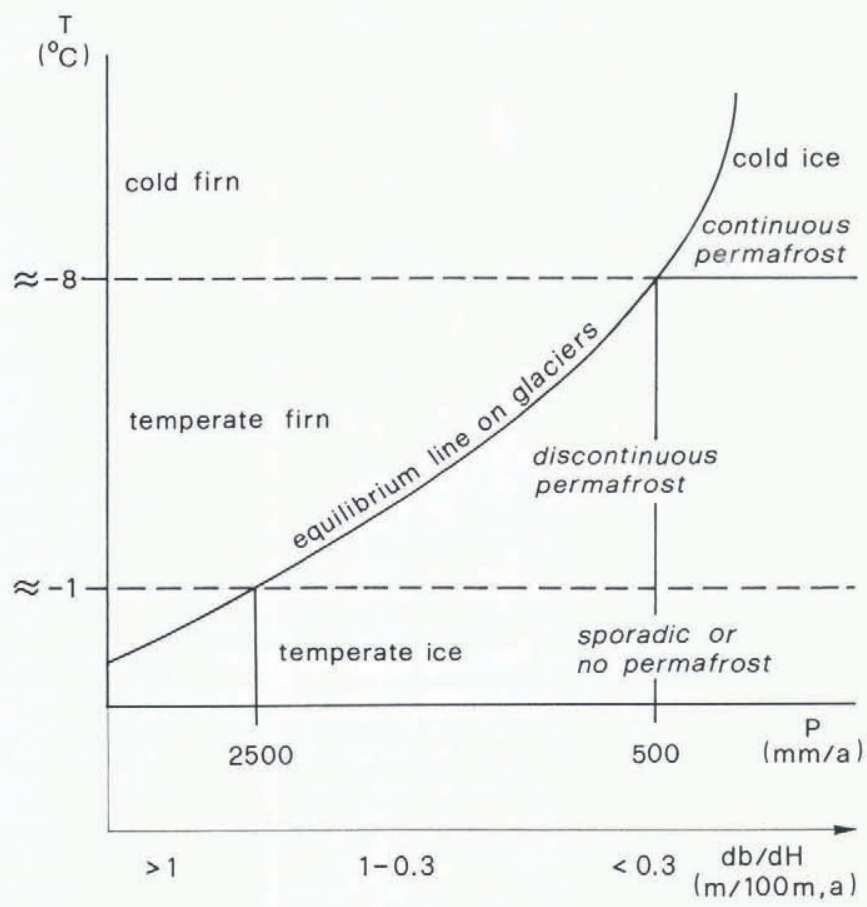

Fig. 1. Scheme of cryosphere as function of mean annual air temperature $(T)$ and average annual precipitation $(P)$ for estimating near-surface temperatures conditions, mass-balance gradients $(\mathrm{d} b / \mathrm{d} H)$ and glacier/permafrost relations.

gradients within the ablation area $(\mathrm{d} b / \mathrm{d} H)$ can be inferred using the scheme for the cryosphere as depicted in Figure 1. This scheme is based on empirical data related to englacial temperatures (Hooke and others, 1983; Haeberli and Alean, 1985), mass-balance gradients (Kuhn, 1981; Boulton and others, 1984), precipitation/ELA relations (Kerschner, 1985), and glacier/permafrost relationships (Haeberli, 1983a). Note that, like permafrost temperatures, near-surface ice temperatures in the ablation area are temperate or roughly $3^{\circ}$ to $4^{\circ} \mathrm{C}$ higher than mean annual air temperatures, MAAT, but cold firn occurs at MAAT $=-8^{\circ}$ to $-10^{\circ} \mathrm{C}$ only, due to melt-water percolation effects. In the absence of sophisticated flow models, only qualitative descriptions (cold, partially cold, temperate) of thermal conditions at the glacier bed can be given. Mean basal shear stress, $\tau$, can best be approximated as a function of $D H$ and $\mathrm{d} b / \mathrm{d} H$, the product of which governs the total mass turnover (Haeberli, 1985); in principle, this corresponds to an inverse ice-flow law, treating the average basal shear stress as a dependent variable of the climatically and topographically controlled shear strain-rate, (Haeberli and Schweizer, 1988). Mean glacier thickness, $\bar{h}$, and total ice volume, $V$, are now easily calculated from empirical relations between $S$ and $\bar{h}$ (Müller and others, 1976) or from the shear-stress equation in its simplest form (Paterson, 1981). Mean flow velocity at the surface, $\bar{u}$, is derived from a balance-velocity concept (Budd and Allison, 1975) or from an empirically calibrated ice-flow formula

$$
\bar{u}=\frac{4 A}{n+1} \bar{\tau}^{n} \bar{h}
$$

where $A$ and $n$ are chosen to be $0.08 \operatorname{bar}^{-3} \mathrm{a}^{-1}$ and 3 , respectively, and sliding at temperate beds is assumed to be equally important as ice deformation with regard to surface velocity (Haeberli and Penz, 1985).

\section{GLACIER-LENGTH VARIATIONS}

Changes in glacier extent, and especially glacier length, can directly cause undesired contact with man-made constructions and lead indirectly to the formation of ice avalanches and glacier floods; they must therefore be taken into account with respect to various time periods as a function of reasonable scenarios of cumulative mass balance. It is often sufficient for mass balance to consider the continuation of the strongest trend observed in the past, the reversal of this trend, and a steady-state condition. The choice of the method for estimating glacier-length changes is in turn mainly influenced by availability of information and by the time interval to be considered. Depending on the availability of measurements, there are four levels of sophistication at which prediction can be made: 1. visual interpretation of unmeasured glaciers, 2. simple rules and analogies for roughly parameterized glaciers, 3. extrapolation of trends from measured data series, and 4. fully calibrated flow models. However, the reliability of the prediction does not increase proportionally with the complexity of the applied model. The considered time interval, $I$, is best defined relative to the glacier reaction time, $t_{\mathrm{R}}$ which is the time lag between a change in mass balance and the first appearance of its effects at the glacier margin. Only mechanically stable glaciers are discussed, because the mechanical instability of surging glaciers, of glaciers calving into lakes or becoming submerged in artificial reservoirs (Funk and Röthlisberger, 1989) and of glaciers which mainly ablate by ice avalanching need special treatment.

1. Visual interpretations of unmeasured glaciers have sometimes to be made in urgent cases and can only relate to $I \ll t_{\mathrm{R}}$. The basis for such rough, first-order assessments is a perfect-plasticity assumption for ice flow combined with experience from field observations as summarized by Müller (1988a). Advancing glacier margins flow under roughly constant $\bar{\tau}$ values and therefore exhibit a parabolic convex longitudinal profile. Advancing ice fronts are most often steep and debris-free, and have a terminal moraine ridge or a white basal layer of over-ridden winter snow (Fig. 2). Vegetation may be in direct contact with the ice, and subglacial melt water usually reaches the ice margin in heavily deformed or completely squeezed channels. Retreating ice margins have $\tau \rightarrow 0$ and correspondingly exhibit flat, debris-covered surfaces and large or collapsed melt-water channels. Unfortunately these individual criteria are not reliable predictors, and even when combinations of criteria have been considered judgements sometimes remain uncertain.

2. When using nearby and regularly observed glaciers as analogies, morphological characteristics of the compared ice bodies are more important than regional proximity (Reynaud, 1980). Simple rules can be applied to estimate roughly the influence of morphological parameters for $I \geqslant t_{\mathrm{R}}$, such as:

$$
\begin{gathered}
t_{\mathrm{R}}=L_{\mathrm{a}} / \bar{c} \text { where } \bar{c}=k_{0} \bar{u} \\
D L=L_{0} D b / A
\end{gathered}
$$

where $D L$ is the length change of a glacier after full response and due to a step change in mass balance $D b, L_{0}$, $L_{a}$ is the length of the central flow line of the entire

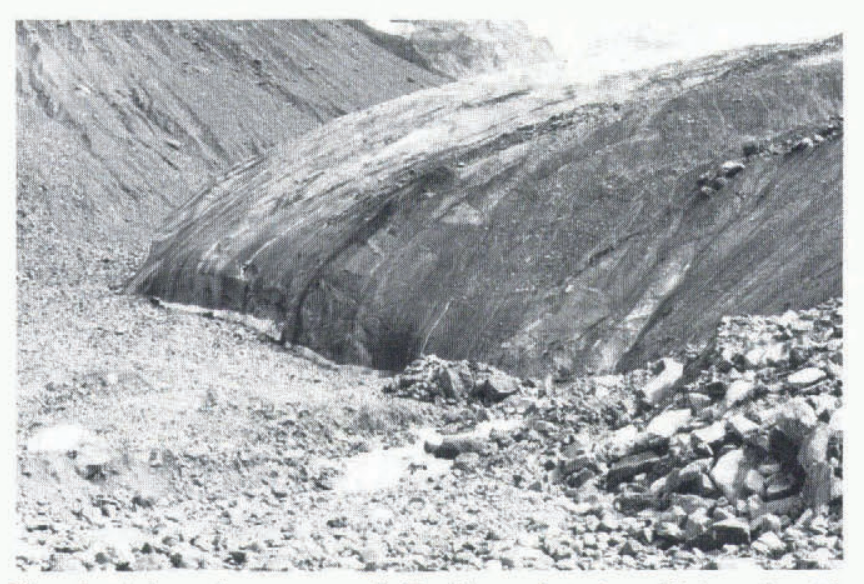

Fig. 2. Advancing snout of Tschiervagletscher (Grisons) with parabola-like surface profile, white layer of over-ridden winter snow (left), and active terminal moraine (right). Melt-water channel is completely squeezed. (Photograph by P. Müller, August 1984.) 


$\begin{array}{lccccccc}\text { Glacier } & D b & A & L_{0} & L_{\mathrm{a}} & \bar{u} & D L & t_{\mathrm{R}} \\ & (\mathrm{m} / \mathrm{a}) & (\mathrm{m} / \mathrm{a}) & (\mathrm{m}) & (\mathrm{m}) & (\mathrm{m} / \mathrm{a}) & (\mathrm{m}) & (\mathrm{a}) \\ \text { Aletsch } & 0.3 & 10 & 25000 & 15000 & 100 & 750 & 30 \\ \text { Belevedere } & 0.3 & 5 & 6000 & 4000 & 50 & 350 & 15 \\ \text { Locce } & 0.3 & 3 & 3000 & 1000 & 50 & 300 & 5\end{array}$

glacier and of the ablation area, respectively, $A$ is the annual ablation at the glacier snout and $\bar{c}$ is the average velocity of kinematic wave propagation (cf. Paterson, 1981). On the basis of reliable statistics applied to a sample of well-documented Swiss glaciers, Müller (1988a) estimated that $k_{0}=5-6$. He also indicated that the relation between $\bar{c}$ and $h$ for glaciers with comparable shear stresses is approximately linear, as would be expected from kinematic wave theory. Table I gives three examples of quantitative estimates. As a result of the pronounced change in the trend of Alpine cumulative mass balance in the mid 1960s, the terminus of Aletschgletscher is not expected to react before the 1990s, whereas Ghiaccaio del Belvedere at the foot of Monte Rosa in the Italian Alps has recently started to advance and to threaten tourist installations. Ghiacciaio delle Locce, a short and steep tributary glacier of Ghiacciaio del Belvedere, had already started to advance by the mid 1970s, if not earlier, and caused a devastating lake outburst in 1979 (Haeberli and Epifani, 1986). Advance velocities of Swiss glaciers, measured since 1950, were compiled by Müller (1988a). Extremes of $50-200 \mathrm{~m} / \mathrm{a}$ can occur on steep glaciers over time periods of $1-5$ years, but averages are more typically $5-20 \mathrm{~m} / \mathrm{a}$.

3. Extrapolation of trends from measured length changes by multiple regression with meteorological or mass-balance data (Reynaud, unpublished) can be made if data series are available which extend back over time periods considerably greater than that of $t_{R}$. Müller (1988b) used a twodimensional and statistically calibrated model for extrapolating glacier-margin developments, documented by repeated photogrammetric determinations of selected longitudinal profiles

$$
\mathrm{d} x_{i}=k^{*}\left[\frac{\mathrm{d} Q_{i}}{h_{0, i-1}+L_{i-1}}\right]+k^{* *}\left\{1-\frac{\left(2 \bar{\tau} L_{i-1}\right)^{\frac{1}{2}}}{(\rho g)^{1 / 2} h_{0, i-1}}\right\}
$$

with $\mathrm{d} x, \mathrm{~d} Q$ as changes in length and ice discharge through $\mathrm{h}_{0}$ respectively at time (year) $i, h_{0, i-1}, L_{i-1}$ are ice thickness at starting point and length of the considered profile respectively at time (year) $i-1, \rho$ is the ice density, $g$ is the acceleration due to gravity, $k^{*}$ and $k^{* *}$ are factors for statistical adjustment. The first term of the right-hand side of Equation (4) reflects the continuity assumption, whereas the second term allows a tongue geometry with constant, $\bar{\tau}$, to be included as a prerequisite for retreat/advance transitions. Ice thickness must be measured by radio-echo sounding or other appropriate methods, and $Q$ as a function of time, $t$, is assumed to be proportional to the product of $\sin ^{n} \alpha(t) h^{n+1}(t)$. Müller (1988b) gave an example of such predictive study from Grubengletscher, which is presently advancing towards and over a flood protection structure at the border of an ice-dammed lake.

4. Complex time-dependent flow models can be used (Bindschadler, 1980) if they can be calibrated by longduration series of measured data on mass balance, flow, and advance/retreat; this is the case for only an extremely small number of glaciers throughout the world. However, finiteelement modelling of glaciers which have been adequately parameterized over short time periods of a year or two can be a very useful tool for sensitivity studies. In the case of the advancing Ghiacciaio del Belvedere, for instance, the relative influence on the near-future ice-front activity from the present-day tongue geometry and from assumed changes in ice flux from the accumulation area, was investigated with such an approach (Versuchsanstalt für Wasserbau, unpublished). For time periods $I \gg t_{\mathrm{R}}$, model calculations of any type are of very little use because of the uncertainty of future climatic and mass-balance developments. Despite this, however, it is, reasonable to assume that glaciers can reach the same maxima and minima over the next few decades as those recorded in past decades. In the Alps, the 1920 advance and the 1960 minimum ice extent are good reference points for small and medium-sized glaciers. Earlier topographical maps, field mapping of moraines, lichens and trees, or records on past glacier fluctuations form the basis for the corresponding estimates (Holzhauser, 1984).

\section{ICE AVALANCHES}

The basis for dealing with ice-avalanche problems has been extensively discussed by Alean (1984a, 1985a) Historical events in the Alps are known to have involved volumes of up to a few million cubic metres, and to have reached horizontal run-out distances of up to about $6 \mathrm{~km}$; with even higher values known from other mountain areas of the world. Proceeding from such historically documented extreme run-out distances, the area where potentially dangerous ice avalanches may start can be roughly defined as a first step. Factors affecting the stability of ice on steep slopes are adhesion of temperate and cold ice on bedrock, cohesion with more stable up-slope ice, shear strength with respect to lateral abutments, and support both from down-slope ice and more especially from cold ice margins frozen to bedrock if the starting zone is not (yet) at the terminus (Röthlisberger, 1981). The relative importance of these factors cannot safely be assessed even after the event has occurred, and visual interpretation of crevasse patterns is often difficult and misleading (Röthlisberger, 1987). The most simple criteria must therefore be applied. It is appropriate to discriminate between two main types of idealized bedrock morphology with respect to potential starting zones such as ramps and breaks. Processes concerning breaks in bedrock slope are similar to those in calving at ice cliffs into water bodies (Iken, 1977; Alean, 1985b) and often, but not always, involve relatively minor volumes. Ramp-type starting zones can release very large volumes, and in such cases the critical slope for possible avalanche formation appears to increase with increasing altitude and decreasing bed temperature (Alean, 1985a). Major ice avalanches from cold ramps in permafrost areas can occur during the whole year, whereas they seem to be limited, possibly only to the late melt season, on temperate ramps. This confirms that the existence of a critical bedrock slope alone represents a necessary condition for the formation of large avalanches on ramps although it is not the only condition.

Run-out distances of potential ice avalanches are estimated using empirical one-parameter or average slope models (Alean, 1985a). As a first approximation for the Swiss Alps, the maximum run-out distance of an ice avalanche can be assumed to be three times the height of the chute, independent of avalanche volume. The fact that at least on firn surfaces, single sliding blocks can travel as far as large avalanches is especially important with respect to ski runs in or below serac zones of glaciers (Alean, 1984b). In some cases, shorter run-out distances can be 

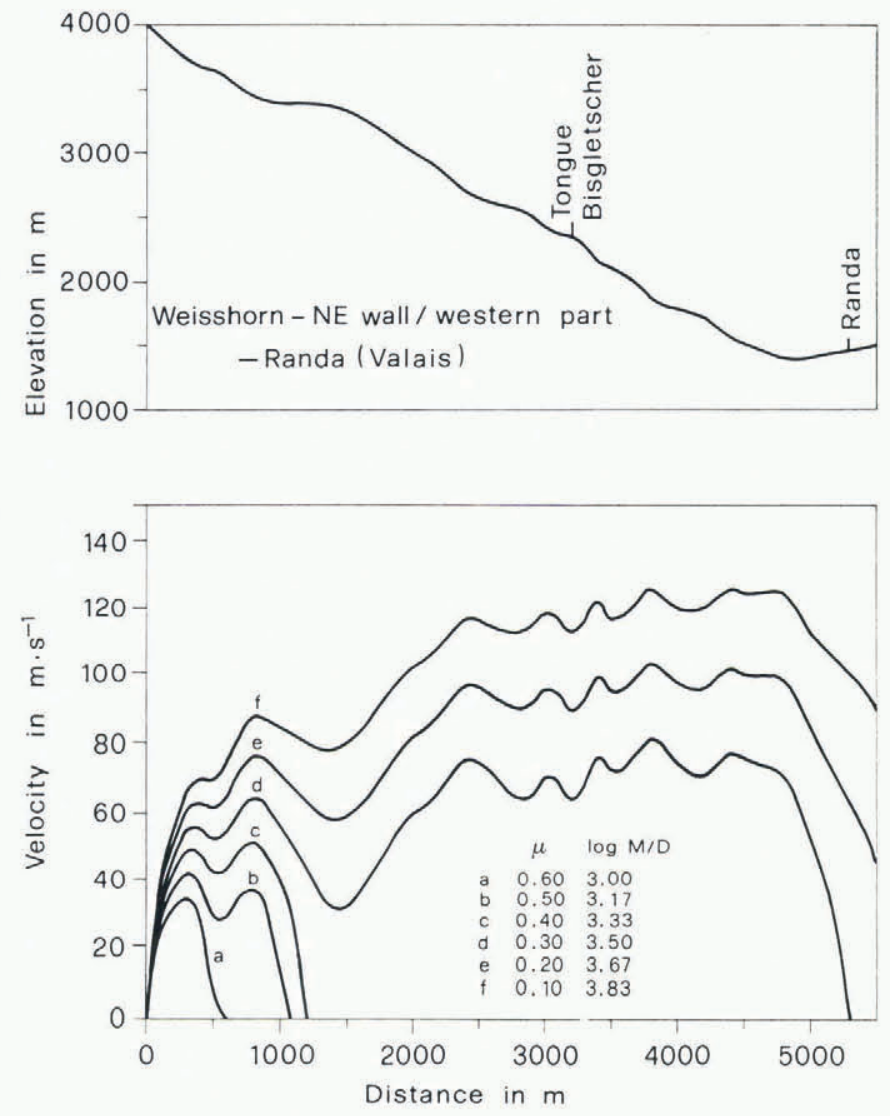

Fig. 3. Two-parameter model calculation of ice avalanches on Weisshorn near Randa, Matter Valley, with topography of chute (top) and flow velocities for various combinations of frictional parameter $\mu$ and "mass-to-drag ratio" $(M / D)$ (bottom). Experience shows that processes of mass change on snow-covered slopes (winter) or in heavily crevassed zones (summer) play an important if not predominant role with respect to run-out distance.

assumed on the basis of characteristic terrain configurations as discussed by Alean (1985a). However, due to the limited size of the documented sample of experienced events and the still poor understanding of the processes involved, such a procedure introduces significant uncertainties.

If flow velocities have to be taken into account in relation to potential flood waves in lakes and reservoirs two-parameter models are asked for concerning calving waves (cf. Haeberli, 1977; Vischer, 1979). The models used for snow avalanches are being applied, but because measured ice-avalanche velocities are hardly ever available the frictional parameters need to be calibrated in an improvised way, such as from documented air jumps or ascents on slopes opposite the avalanche path (Voight, 1981; Körner, 1983; Alean, 1984a). Figure 3 shows an example of avalanches from the Weisshorn near Randa, Valais, and illustrates the scatter and some of the uncertainties involved in calculations of this type. The most severe problems concern the validity of the basic assumptions of the model; the frictional parameters are almost certainly not constant along the avalanche path, significant mass changes can occur on snow-covered slopes including mass gain (Fig. 4) and in crevasse zones of glaciers or concave slopes/terraces and mass loss (Fig. 3). Strong longitudinal extension often takes place within the avalanching ice debris. Forecasts are therefore necessarily semi-quantitative and must be correspondingly accompanied by explanatory text.

\section{GLACIER FLOODS}

Floods, debris flows, and mud flows from glaciers usually represent the farthest reaching glacier hazard to be considered and hence essentially determine the outermost limits of potentially endangered zones in mountain regions. A large variety of processes can take place with respect to

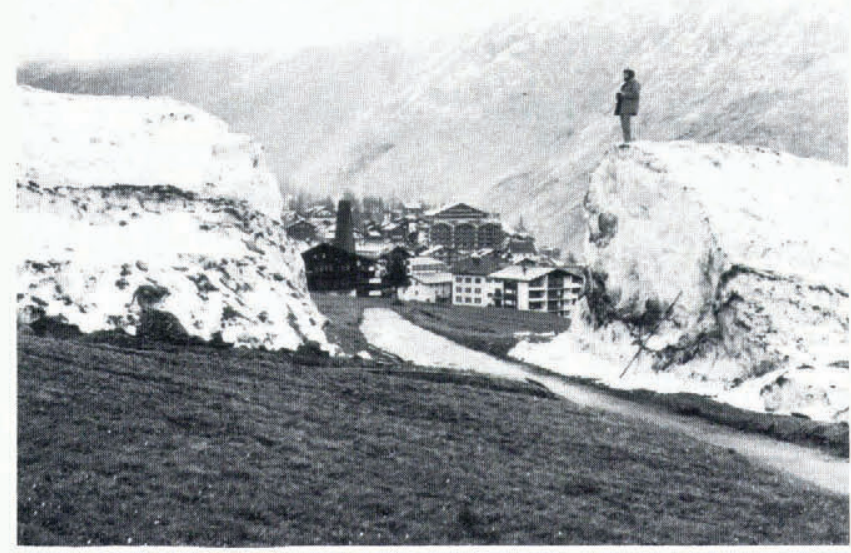

Fig. 4. Combined snow/ice-avalanche from Hohbalmgletscher near Saas Fee (background) caused destruction of skilif $t$ ski run had been closed because of heavy snowfall and corresponding avalanche danger. (Photograph by W. Haeberli, May 1981.)

the formation of water reservoirs, the outburst mechanisms, and the processes in the outlet stream (Haeberli, 1981, 1983b). Devastating outbursts of invisible water pockets are apparently rare although they can obviously occur in glaciers exhibiting a variety of morphological characteristics. It is not practicable to predict such events by any currently available methods and they therefore constitute an important base level of unavoidable risk which is commonly accepted in mountain areas. Extreme values of outburst volumes and peak discharges measured in the Alps are in the order of $1-2 \times 10^{6} \mathrm{~m}^{3} / \mathrm{s}$ and $100-200 \mathrm{~m}^{3} / \mathrm{s}$, respectively. Because gauging stations were often destroyed in the course of major events, exact values are seldom available.

With the exception of cases involving glacial surges and water-pocket ruptures, natural melt-water reservoirs tend to form slowly and visibly in supra-, pro- and periglacial sites and at lateral ice margins. Morphological characteristics heavily influence outburst mechanisms. These morphological characteristics, and the development of flood hazards can usually be monitored by repeated visual observation, aerial photography or surveying. Outbursts of lakes can be triggered by calving waves or waves induced by rock, snow, and ice avalanches. In the ice itself, progressive enlargement of ice channels can take place when sealing glacier parts become afloat or as a result of ground-water flow in sedimentary glacier beds. Dams consisting of heavily broken ice from glacier surges or ice avalanches tend to give way suddenly.

Overtopping and consequent erosion of ice dams seems to be more common in regions with cold ice and permafrost. In general, these events are less dangerous than events involving other outburst mechanisms. Pro-glacial lakes can suddenly empty by retrogressive erosion of the spillway, by progressive ground-water flow (piping), or by slope instability in steep moraines. All these processes require a high water level and then probably occur in combination. In the melt-water stream, the formation of flood waves or debris flows (Fig. 5) depends mainly on the availability of non-consolidated sediments, but also on channel slope, outburst volume, and peak discharge.

Despite the considerable number of published scientific reports concerning glacial floods, the possibility of making quantitative assessments and forecasts is severely limited. Empirical relationships between maximum discharge during breach, $Q_{\max }$, and outburst volume, $V$, for man-made and natural dams (Evans, 1986) tend greatly to overestimate the peak discharge from glacial floods. On the other hand, the famous Clague-Mathews relationship

$$
Q_{\max } \leqslant 75\left(V / 10^{6}\right)^{0.67}
$$

(Clague and Mathews, 1973) is valid for progressive enlargement of channels only, and greatly underestimates possible peak discharge values for sudden break cases in ice. Estimating $Q_{\text {mx }}$ for such cases (Haeberli, 1983) with the equation using the time constant, $t_{\mathrm{D}}$ 


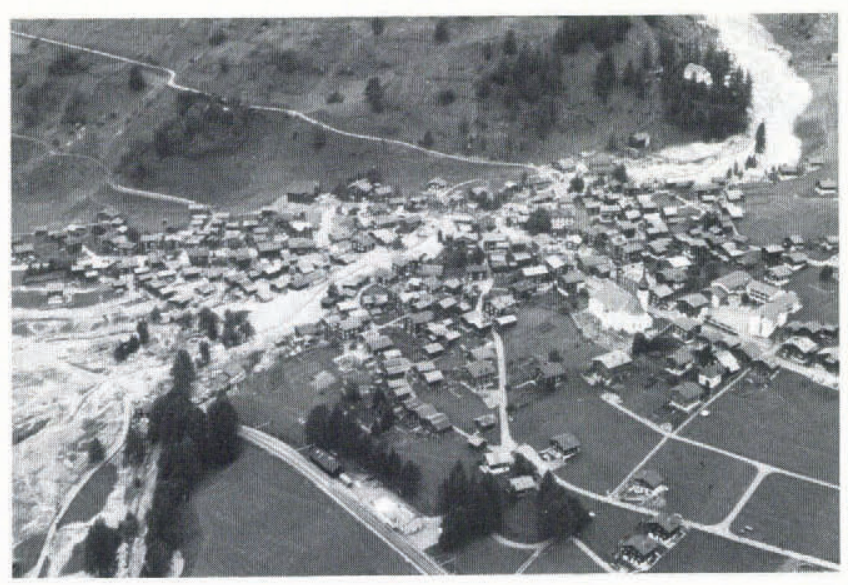

Fig. 5. Debris flow through Münster, Goms/Valais, following extreme precipitation. Starting zone of debris flow was a steep, debris-filled gorge immediately beneath tongue of Minstigergletscher. A comparable event, also causing heavy damage, took place at Poschiavo, Grisons, during same summer. (Photograph by W. Haeberli, August 1987.)

$$
Q_{\max } \leqslant V / t_{\mathrm{D}}
$$

we find that its value varies greatly, and probably increases from a minimum of about $1000 \mathrm{~s}$ for small values of $V$ to higher and therefore less dangerous values with large $V$. The examples of the historical surges and lake outbursts at Vernagtferner and Glaciar Grande del Nevado del Plomo (Helbling, 1925; Lanser, 1959; Bruce and others, 1987) illustrate that progressive enlargement of channels and sudden rupture of heavily broken ice can occur together and then lead to intermediate peak discharge values. In the case of the Plomo flood of 1934, an aerial photograph (thought to have been taken by E. Pilditch) is available (Helbling, 1935) which indeed indicates partial collapse of the ice dam. More sophisticated models of glacier hydraulics (Spring and Hutter, 1981; Clarke, 1982) are best used for carrying out sensitivity studies with respect to potential flood hydrographs for modelling flood-wave propagation in stream channels.

Stability of morainic dams can be investigated by analysing possible failure due to slippage or liquefied flow, piping, and overtopping (Youd and others, 1981). Slippage of cohesion-less material requires steep slopes of the failure surface as well as high ground-water levels, and is most likely to occur in the immediate neighbourhood of the river course. Hydraulic gradients critical for piping are very high and can be reached below extremely narrow ice dams. This is thought to have led to the collapse of the ice-debris dam of Giétro glacier in 1818 (Röthlisberger, 1981), similarly high gradients are locally reached where cavities from melted dead ice or permafrost exist in the morainic material. A depth of $10-15 \mathrm{~m}$, and a cross-sectional area of $500 \mathrm{~m}^{2}$ represent extreme values observed in the Alps for the erosional capacity of streams in loose morainic material during catastrophic floods. This empirical limit is probably related to the relatively small outburst volumes existing in rugged mountain topography, and to effects of natural paving within the stream channel which take place during the process of erosion (Haeberli, 1981, 1983b). Debris flows are assumed to form wherever the amount of entrained debris exceeds the amount of water. Their reach has to be roughly assessed on the basis of a small number of events with observed or reconstructed peak discharge values and measured average slopes of the run-out distances (Haeberli, 1983b).

\section{SYNOPSIS AND ASSESSMENTS}

Estimates of potential glacier hazards can be summarized by verbal descriptions or graphical representations, depending on the specific requirements in a given situation. In the case of permanently and traditionally inhabited areas, the production of maps depicting assumed hazard zones is especially delicate and requires careful explanation in order to avoid grave misunderstandings or unproportionate reactions. Figure 6 shows an example from the Saas Valley in the Valais, where many events have occurred (Indermühle, 1986). Such graphical representations serve as a basis for discussion, and are easily comprehended synopses of quite uncertain glaciological reflections. They are, however, not more and not less than this; not more, because they have no legal implications in themselves, and not less, because withholding such information would be dishonest.

In the case of the Saas Valley, most villages are obviously situated within the reach of potential glacier hazards. However, the same has been true throughout the whole historical lifetime of these settlements (Tufnell, 1984; Grove, 1987). This clearly shows that the risks from glacier hazards has generally been accepted, and makes it possible to understand why measures were taken only after heavy damage had occurred. The risk from glacier hazards as defined by the probability that an incident will occur within a given period of time, can neither be assessed quantitatively nor described as negligible. The frequency and seriousness of accidents due to glacier hazards are, in fact, somewhere in between the rather periodical phenomena of precipitation-induced floods, earthquakes or snow avalanches,

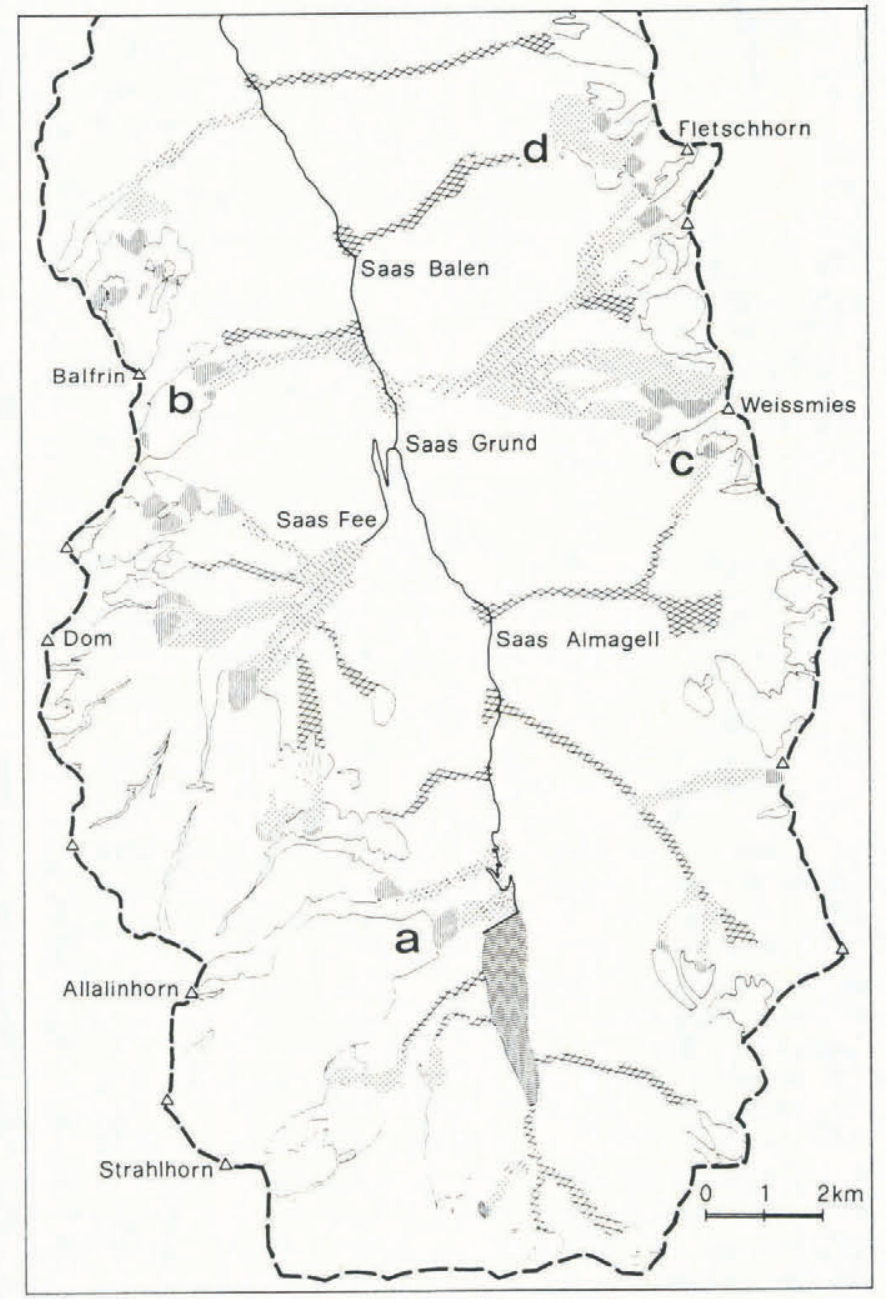

Fig. 6. Map of potential glacier-derived debris flow (criss-crossed screen), and potential starting zones (dark screen) and run-out paths (point screen) of ice avalanches in Saas Valley after Indermühle (1986). Common run-out paths of debris flows and ice avalanches (indicated by -.-.-.). During the twentieth century, major ice avalanches occurred at (a) Allalingletscher (Mattmark, 1965) and (b) Bidergletscher (Saas Bidermatten, 1928), and important glacier-derived debris flows from (c) Rottalgletscher (Saas Almagell, 1953), and (d) Grubengletscher (Saas Balen, 1968, 1970) reached valley bottom 
and highly episodical events such as landslides or major rock falls. For the Saas Valley, the return period of accidents due to glacier hazards is in the order of years or decades for the entire valley, and in the order of decades or centuries for individual sites. The risk of being hurt or even killed by such accidents should be compared with other risks commonly accepted in private life, from sports, car traffic, and similar sources.

Assessing risks from glacier hazards in the manner discussed in the present paper can, at best, be a reasonable and transparent way of transferring the available but incomplete historical experience from the past to the present or of making it available for the future, and a means of extrapolation from well-documented sites to less-welldocumented ones. Such a transfer appears to be especially important with regard to modern construction work in high-mountain regions. Hydro-electric power schemes and tourist installations enter previously avoided zones of recognizably high risk from glacier hazards more and more frequently, yet even in such cases careful comparison with other hazards and other sites must influence the decision about what are possible measures. It would, for instance, be inappropriate to impose much heavier restrictions on a ski run than on a nearby and permanently inhabited village, if both were threatened by the same type of event. On the other hand, strict prescriptions must be followed if an installation has the potential of markedly enhancing the hazard from an otherwise acceptable risk, such as for instance an artificial reservoir within the reach of calving glacier fronts, ice avalanches, or major glacier floods. Because of the small number of glaciologists who have practical experience on problems involved with glacier hazards, international expertise can be sought following the occurrence of an accident or of a threatening development. An improved exchange of information at an international level is therefore urgently needed and critical feed-back to the opinions discussed in the present article would be highly welcome.

\section{REFERENCES}

Alean, J.-C. 1984a. Ice avalanches and a landslide on Grosser Aletschgletscher. Z. Gletscherkd. Glazialgeol., 20, 9-25.

Alean, J.-C. 1984b. Untersuchungen über Entstehungsbedingungen und Reichweiten von Eislawinen. Eidg. Tech. Hochschule, Zürich. Versuchsanst. Wasserbau. Hydrol. Glaziol. Mitt. 74.

Alean, J.-C. 1985a. Ice avalanche activity and mass balance of a high-altitude hanging glacier in the Swiss Alps. Ann. Glaciol., 6, 248-249.

Alean, J.-C. 1985b. Ice avalanches: some empirical information about their formation and reach. J. Glaciol., 31(109), 324-333.

Bindschadler, R. 1980. The predicted behavior of Griesgletscher, Wallis, Switzerland, and its possible threat to a nearby dam. Z. Gletscherkd. Glazialgeol., 16(1), 45-59.

Boulton, G.S., G.D. Smith, and L.W. Morland. 1984. The reconstruction of former ice sheets and their mass balance characteristics using a non-linearly viscous flow model. $J$. Glaciol., 30(105), 140-152.

Braithwaite, R.J. and F. Müller. 1980. On the parameterization of glacier equilibrium line altitude. International Association of Hydrological Sciences Publication 126 (Workshop at Riederalp 1978 - World Glacier Inventory), 263-271.

Bruce, H.R., G.A. Cabrera, J.C. Leiva, and L.E. Lenzano. 1987. The 1985 surge and ice dam of Glaciar Grande del Nevado del Plomo, Argentina. J. Glaciol., 33(113), 131132.

Budd, W.F. and I.F. Allison. 1975. An empirical scheme for estimating the dynamics of unmeasured glaciers. International Association of Hydrological Sciences Publication 104 (General Assembly of Moscow 1971 - Snow and Ice), 246-256.

Clague, J.J. and W.H. Mathews. 1973. The magnitude of jökulhlaups. J. Glaciol., 12(66), 501-504.

Clarke, G.K.C. 1982. Glacier outburst floods from "Hazard Lake", Yukon Territory, and the problem of flood magnitude prediction. J. Glaciol., 28(98), 3-21.

Evans, S.G. 1986. The maximum discharge of outburst floods caused by the breaching of man-made and natural dams. Can. Geotech. J., 23(3), 385-387.

Funk, M. and H. Röthlisberger. 1989. Forecasting the effects of a planned reservoir which will partially flood the tongue of Unteraargletscher in Switzerland. Ann. Glaciol., 13, 76-81.

Gross, G., H. Kerschner, and G. Patzelt. 1977. Methodische Untersuchungen über die Schneegrenze in alpinen Gletschergebieten. Z. Gletscherkd. Glazialgeol., 12(2), 1976, 223-251.

Grove, J.M. 1987. Glacier fluctuations and hazards. Geogr. J., 153(3), 351-369.

Gubler, H. 1986. Temporäre und permanente Lawinenschutzmassnahmen für touristische Anlagen. Eidg. Inst. Schnee- Lawinenforsch., Weissfluhjoch-Davos. Mitt. 45 .

Haeberli, W. 1977. Experience with glacier calving and air-bubbling in high Alpine water reservoirs. J. Glaciol., 19(81), 589-594

Haeberli, W. 1981. Morphodynamische Aspekte aktueller Gletscherhochwasser in den Schweizer Alpen. Reg. Basil., 21(3), 58-78

Haeberli, W. 1983a. Frequency and characteristics of glacier floods in the Swiss Alps. Ann. Glaciol., 4, 85-90.

Haeberli, W. 1983b. Permafrost-glacier relationships in the Swiss Alps - today and in the past. In Permafrost: Fourth International Conference, July 17-22, 1983. Proceedings. Washington, DC, National Academy Press, 415-420.

Haeberli, W. 1985. Global land-ice monitoring: present status and future perspectives. In Glaciers. Ice Sheets, and Sea Level: Effect of a $\mathrm{CO}_{2}$-induced Climatic Change. Report of a Workshop held in Seattle. Washington, September 13-15, 1984. Washington, DC, United States Department of Energy, 216-231.

Haeberli, W. and J. Alean. 1985. Temperature and accumulation of high altitude firn in the Alps. Ann. Glaciol., 6, 161-163.

Haeberli, W. and F. Epifani. 1986. Mapping the distribution of buried glacier ice - an example from Lago delle Locce, Monte Rosa, Italian Alps. Ann. Glaciol., 8, 78-81.

Haeberli, W. and U. Penz. 1985. An attempt to reconstruct glaciological and climatological characteristics of $18 \mathrm{ka}$ BP Ice Age glaciers in and around the Swiss Alps. $Z$. Gletscherkd. Glazialgeol., 21, 351-361.

Haeberli, W. and J. Schweizer. 1988. Rhonegletscher 1850: eismechanische Ueberlegungen zu einem historischen Gletscherstand. Eidg. Tech. Hochschule, Zürich. Versuchsanst. Wasserbau. Hydrol. Glaziol. Mitt. 94, 59-70.

Helbling, R. 1935. The origin of the Rio Plomo ice-dam. Geogr. J., 85(1), 41-49.

Holzhauser, H. 1984. Zur Geschichte der Aletschgletscher und des Fieschergletschers. Physische Geographie, Zürich, 13.

Hooke, R. LeB., J.E. Gould, and J. Brzozowski. 1983. Near-surface temperatures near and below the equilibrium line on polar and subpolar glaciers. Z. Gletscherkd. Glazialgeol., 19(1), 1-25.

Iken, A. 1977. Movement of a large ice mass before breaking off. J. Glaciol., 19(81), 595-605.

Indermühle, P.-F. Unpublished. Essai pilote de carthographie des dangers liés aux glaciers, en tant que contribution à l'aménagement régional. (Diploma thesis, Université de Fribourg, Switzerland, 1986.)

Jaccard, C. 1988. De la recherche à son application: réflections sur certains écueils. Eidg. Tech. Hochschule, Zürich. Versuchsanst. Wasserbau. Hydrol. Glaziol. Mitt. 94, 345-352.

Kerschner, H. 1985. Quantitative paleoclimatic inferences from lateglacial snowline, timberline and rock glacier data, Tyrolean Alps, Austria. Z. Gletscherkd. Glazialgeol., 21, 263-369.

Kienholz, H. 1981. Zur Methodologie der Beurteilung von Naturgefahren. Geomethodica Basel, 6, 25-56.

Kienholz, H., G. Schneider, M. Bischel, M. Grunder, and P. Mool. 1984. Mapping of mountain hazards and slope stability. Mountain Research and Development, 4, $247-266$. 
Körner, H.J. 1983. Zur Mechanik der Bergsturzströme vom Huascaran, Peru. Hochgebirgsforschung, Innsbruck, 6, 71-110.

Kuhn, M. 1981. Climate and glaciers. International Association of Hydrological Sciences Publication 131 (Symposium at Canberra 1979 - Sea Level, Ice, and Climatic Change), 3-20.

Lanser, O. 1959. Beiträge zur Hydrologie der Gletschergewässer. Schriftenr. Oesterr., Wasserwirtschaftsverb., 38.

Müller, F., T. Caflisch, and G. Müller. 1976. Firn und Eis der Schweizer Alpen. Gletscherinventar. Eidg. Tech. Hochschule, Zürich. Geogr. Inst. Publ. 57.

Müller, P. 1988a. Betrachtungen zur Entwicklung des Grubengletschers im Bereich des Sees 3 anhand eines einfachen Modelles. Eidg. Tech. Hochschule, Zürich. Versuchsanst. Wasserbau, Hydrol. Glaziol. Mitt. 94, 99108.

Müller, P. 1988b. Parametrisierung der Gletscher-KlimaBeziehung für die Praxis: Grundlagen und Beispiele. Eidg. Tech. Hochschule, Zürich. Versuchsanst. Wasserbau, Hydrol. Glaziol. Mitt. 95.

Paterson, W.S.B. 1981. The physics of glaciers. Second edition. Oxford, etc., Pergamon Press.

Reynaud, L. Unpublished. Etudes des fluctuations de longueur du glacier de Findelen en fonction du rythme d'alimentation et prévision de l'évolution future. Communication to Grande Dixence SA, Sion, Switzerland.
Röthlisberger, H. 1981. Eislawinen und Ausbrüche von Gletscherseen. Jahrb. Schweiz. Naturforsch. Ges., 1978, 170-212.

Röthlisberger, H. 1987. Sliding phenomena in a steep section of Balmhorngletscher, Switzerland. J. Geophys. Res., 92(B9), 8999-9014.

Spring, U. and K. Hutter. 1981. Numerical studies of jökulhlaups. Cold Reg. Sci. Technol., 4(3), 227-244.

Tufnell, L. 1984. Glacier hazards. London and New York, Longman.

Versuchsanstalt für Wasserbau. Unpublished. Valutazione dei rischi glaciali nella regione Macugnaga/Monte Rosa. Report 97.4 of Eidgenössische Technische Hochschule, Zürich. Versuchsanstalt für Wasserbau, Hydrologie und Glaziologie.

Vischer, D. 1979. Kalbungswelle beim Aufbrechen einer überstauten Gletscherzunge. Eidg. Tech. Hochschule, Zürich. Versuchsanst. Wasserbau, Hydrol. Glaziol. Mitt. 41, 315-329.

Voight, B. 1981. The 1980 eruptions of Mount St. Helens, Washington. Time scale for the first moments of the May 18 eruption. U.S. Geol. Surv. Prof. Pap. 1250, 69-86.

Youd, T.L., R.C. Wilson, and R.L. Schuster. 1981. The 1980 eruptions of Mount St. Helens, Washington. Stability of blockage in North Fork Toutle River. U.S. Geol. Surv. Prof. Pap. 1250, 821-828. 